\title{
POTENTIAL PLACE FOR GRAVEL AND SAND EXPLOITATION IN THE CIRCULAR ECONOMY
}

\section{Boris Vakanjac ${ }^{1 *}$, Suzana Đorđević - Milošević ${ }^{1}$, Vesna Ristić Vakanjac²}

\author{
'Singidunum University \\ Belgrade Serbia \\ 2University of Belgrade, Faculty of \\ Mining and Geology, Belgrade, \\ Serbia
}

\begin{abstract}
:
Riverbeds and coastal parts of major rivers in their lower parts have significant resources of gravel and sand which are of paramount importance for the construction industry. The exploitation of the mentioned resources has negative consequences on the river regime in the first place and on the environment as well. Taking into account that modern world and industry will need these mineral raw materials in the future, it is necessary to find ways to correct the negative consequences or minimize what can be achieved through the circular economy. Open pits remain abandoned after completion of exploitation. They pose a danger for the environment, become wild landfills, a habitat for mosquitoes, insects, and rodents, also they can lead to pollution of groundwater, etc. With a certain amount of investment, these sites can become fishponds, places for walking, swimming, cycling, and other touristic and sport activities.
\end{abstract}

Keywords:

open pit, gravel, sand, environment, circular economy

\section{INTRODUCTION}

Downstream parts of river beds and banks of larger rivers in Serbia such as Great, South and West Morava, then Drina, Ibar, etc. represent significant natural water resources.

The alluviums of mentioned rivers always have been favorable for living conditions. Ancient civilizations situated their settlements to large rivers, and even today, in these parts, there are large capitals in the world. In Serbia, when we talk about the alluvium of Great Morava, there are cities of Paraćin, Jagodina, Batočina, Lapovo, Svilajnac, Velika Plana, Požarevac and Smederevo, also the smaller cities: Barbarian, Glogovac, Markovac, Veliko Orašje, Miloševac, Lozovik, Simićevo, and Oreovica. The Drina River in its downstream parts connects Mali Zvornik, Gornja Koviljača and Banja Koviljača, Loznica, Lipnički Šor, Jelav, Lešnica, Badovinci, Salaš Crnobarski, and Crna Bara at the Republic of Serbia side - bank of the river. Also, there are major cities Bijeljina (the Republic of Srpska) and Bogatić (the Republic of Serbia). For the needs of these cities and settlements, it is necessary to provide sufficient quantities of water for water supply. The population of these cities is provided by water with groundwater which is hydraulically connected to surface flows. Water supply facilities are generally installed parallel to the river flow. For the protection of settlements, water supply facilities and agricultural fields from flood waves, embankments have been constructed parallel to the river flow.

As high-grade lands are developed on river alluviums, intensive agricultural production is active in these areas. During the summer part of the year or the dry periods, it is necessary to provide certain quantities of water to increase the yield per hectare. 
Regarding the mentioned reasons, irrigation is carried out by groundwater.

These rivers, as they have significant water resources, have great potential for electricity production. Here we highlight the river Drina, which has 3 dams from the town of Višegrad to its confluence with the Sava River. The most upstream is the HPP Višegrad, which started operating in 1989, then the HPP Bajina Bašta, which was put into operation in 1966, and the most downstream is the HPP Zvornik, which is oldest and has been operating since 1955. With the construction of these dams, water flow regulation was implemented, so at the downstream parts were reduced the risks of floods and the risks of prolonged droughts.

In addition to water-related resources, riverbeds and riverbanks also contain mineral resources such as gravel and sand, which are of great importance in construction. These renewable significant dam-building resources are becoming non-renewable, so they must be handled with care when exploiting them.

Exploitation of river material (sand and gravel) involves the excavation of river bed the river and from its banks and in general, it can be done in three ways:

- within the riverbank,

- from the river itself (by boat),

- by forming artificial sandbanks.

All three modes of exploitation should be taken into account when the choice of site is carried out, in aim not to impair the stability of the coast and the natural regime of the river. There should be no change in the groundwater regime and it is necessary to maintain the existing balance of biogenesis which is in the ecosystem of a particular locality (Macháček, 2019). Larger rivers such as Great, South and West Morava, Drina, etc. and their beds in their downstream and coastal areas have significant natural resources of sand and gravel. The exploitation of these resources, of different granulations, is of great importance for the construction industry and as such, cannot and should not be stopped. Here we will just adduce which kind of problems uncontrolled exploitation can cause and how abandoned exploitation fields can be used through the circular economy.

\section{GRAVEL AND SAND EXPLOITATION}

Each exploitation of a particular mineral resource has two sides, one that brings prosperity to the region where the exploitation takes place and the other is a permanently disturbed environment. Without mineral resources, it is impossible to imagine today's society. However, as planet Earth is currently the only place where human populations are evolving, the environmental aspect needs to be realistically considered. More specifically, it is necessary to look at the extent to which the environment in some parts has been disturbed and find, if possible, ways to remediate it.

When it comes to the exploitation of gravel and sand, it is important to state here what it implies:

\section{ISSUES CONNECTED WITH GRAVEL AND SAND EXPLOITATION}

The problem arises mainly due to the excessive and uncontrolled exploitation of river beds and their coastal areas in arbitrarily selected locations. These activities are mainly with undefined exploitation conditions, without water management permits and approvals, also without proven reserves of this non-renewable resource (Piyadasa, 2009). All of the above may result in:

1. The violation of the natural regime of surface and groundwater, the stability of river banks, the stability of bridges, embankments, coastal fortification structures, and other hydraulic objects (Byizigiro, Raab, and Maurer, 2015; Nelson and Church, 2012). This happened at the site of the Ljubićev Bridge on the Great Morava River. Due to the excessive and uncontrolled exploitation of gravel and sand, a $5 \mathrm{~m}$ deepening of the bed has occurred, which caused lowering groundwater levels in this area. Wells which were used for water supply had less capacity within the Ključ and Trnovce springs (Popović, Popović, Ristić Vakanjac, Vakanjac and Mandić, 2016; Vakanjac, 2018). Some of the rural draw wells, used for irrigation have even dried up due to the mentioned groundwater level fall (Kihampa and Wenaty, 2013).

2. Excessive and uncontrolled exploitation can cause the river nut to displace. This displacing causes the river banks to become less stable. A good example is the Drina River, which in one part, due to its over-exploitation is: diverted in its riverbed; it has deformed river banks; material which is high-quality agricultural soil is removed (Mandić, Aleksić, Vakanjac and Ristić Vakanjac, 2017). This led to the situation that the Drina River which was a border river between the Republic of Serbia and $\mathrm{BiH}$, cannot be any more and the border is defined by geodetic measuring.

3. The exploitation of gravel in the river bed itself has effects on the concentration of suspended sediment and the turbidity of water. This increases the colmatization of the riverbed which reduces the hydraulic connection of surface and groundwater. Also, the increase in suspended sediment concentration causes a decreases of light in the river water and also decrease the dissolved oxygen level in the water. This has a negative impact on biogenesis living in the river flow.

4. The deepening of the riverbed causes an increase in the hydraulic gradient resulting in further deepening of the riverbed and regressive erosion. 
5. Heavy machinery and trucks used for transporting excavated materials destroy the existing traffic infrastructure, for this the local municipalities in most cases give money. Also, returning trucks, in aim to increase profit, sometimes brings garbage which they unload into abandoned exploitation areas. This contributes that these sites become wild dumps, habitats for mosquitoes and rodents, source of contagions and pollutions, which are difficult to suppress.

6. Often, for a small amount of money, abandoned agricultural land is purchased. From that land is removed a layer of high-quality soil, then the exploitation of gravel and sand begins. Open pits, usually of regular rectangular shape, several meters deep, remain after exploitation. They are dangerous for anyone who uses land fields in the immediate vicinity for agricultural production.

7. In the vicinity of the abandoned mining fields abandoned machinery is left, as well as barrels and buckets in which were tar, oils, petroleum and other organic pollutants. These organic pollutants easily reach the groundwater, which are fully uncovered within the mentioned rectangular open pits. In this way, pollution of the resources which are extensively being used for water supply and irrigation occurs.

\section{CIRCULAR ECONOMY IN THE EXPLOITATION OF GRAVEL AND SAND}

Sand and gravel exploitation can have a major environmental impact (Hilson, 2002; Hilson, 2003; Pitchaiah, 2013). Most of the problems mentioned above can be solved. The solution lies in controlled exploitation, wellchosen location and the mode of exploitation itself. Water turbidity can be eliminated in this way, riverbeds do not to have be devastated, riverbed geometry can be preserved, regressive erosion can be avoided, etc. If all the waste is removed before leaving the exploitation field, the potential groundwater pollution would be minimized.

The aim of this paper is not to commence an initiative to stop the exploitation of gravel and sand. A proposal should be made for the rehabilitation and remediation of abandoned exploitation fields through a circular economy.

Some suggested ways of repairing and valorizing endangered areas:

- existing smaller open pits can become hydrogeological and hydrological objects where fish farming can be carried out. Fish has always been one of the best quality meats so this could bring economic profit to the municipality or society, or to a people who would take the initiative in this direction. Sportfishing could be organized in these areas.;

- some larger abandoned open pits could become local swimming pools. The river water is cold and fast.
Water in isolated parts of the river bed separated by a spruce or in abandoned exploitation pits would be warmer and quieter so that the youngest children could swim during the summer months;

- particular open pits could be connected by walking tracks with accompanying benches for the older visitors, as well as sports equipment for those who want more than just a walk. In addition to walking tracks, bicycle tracks can be set up in parallel with walking ones, for those who like bikes, roller skates, or trotters. For those who want to know more about the biogenesis that resides there, information boards with pictures of birds, animals, insects, and plants, can be set up.

The aforementioned arrangement and adaptation of individual abandoned open pits, to adequate purposes, requires adequate financial support. The funds for this could be obtained by a decree of tax for a certain amount of money per $\mathrm{m} 3$ of excavated material. In this way, devastated areas could be adapted for other purposes. This would bring benefit the nearby residents but also to the tourists who would be attracted by the offer of rural tourism.

\section{CONCLUSION}

The exploitation of gravel and sand is mainly related to the banks or river beds. It carries many negative environmental consequences. In some parts, the environment is completely devastated. Controlled exploitation, well-chosen location, and excavation method can eliminate some negative impacts. Disposal and storage of waste generated during the process of exploitation at pre-prepared sites (regional landfills and scrap yards for old machinery) would reduce the chances of groundwater pollution. The circular economy could turn abandoned exploitation fields into fish ponds, swimming pools, oases for birds who would find their habitat there or migratory birds that would find peace in individual lakes during their season migration, etc. Devastated areas could be transformed into promenades, sports , and bicycle tracks. Along the paths, information boards could be set up to educate visitors. In this way, devastated areas will become places that would be visited by residents of nearby cities as well as tourists.

\section{REFERENCES:}

1. Byizigiro, R. V., Raab, T., Maurer, T. (2015). Small-scale opencast mining: An important research field for anthropogenic geomorphology. Die Erde 2015, 146, 213-231. 49.

2. Hilson, G. M., (2002). The Future of Small-scale mining: environmental and socioeconomic perspectives,Future, Volume 34, Issues 9-10:863-872. $2002 \mathrm{https} / / /$ doi. org/10.1016/S0016-3287(02)00044-7 (15.08.2019) 
3. Hilson, G. (2003). The Socio-Economic Impacts of Artisanal and Small-Scale Mining in Developing Countries, 1st ed.; Taylor \& Francis: London, UK, 2003; ISBN 1135291225.

4. Kihampa, C., Wenaty, A. (2013). Impact of Mining and Farming activities on Water and Sediment Quality of the Mara river basin, Tanzania. Res. J. Chem. Sci. 2013, 3, 15-24.

5. Macháček, J., (2019). Typology of Environmental Impacts of Artisinal and Small-Scale Mining in AFrican Great Lakes Region, Sustainability 2019, 11(11), 3027; https:// doi.org/10.3390/su11113027 (15.08.2019)

6. Mandić, M., Aleksić, J., Vakanjac, B., Ristić Vakanjac, V., (2017). Eksploatacija šljunka i uticaj na životnu sredinu na prostoru donjeg toka reke Drine, Zbornici Srpskog geološkog društva, Rudarsko geološki fakultet (Ed. Zoran Stevanović), pp. 59-68, ISSN 0372-9966

7. Nelson, A. D., Church, M. (2012). Placer mining along the Fraser River, British Columbia: The geomorphic impact. Geol. Soc. Am. Bull. 2012, 124, 1212-1228.

8. Pitchaiah, P. S. (2017). Impacts of Sand Mining on Environment - A Review, International Journal of Geo informatics and Geological Science (SSRG-IJGGS) - Volume 4 Issue 1, 2017, ISSN: 2393 - 9206

9. Piyadasa, R. U. K., (2009). Sediment Problems and Sediment Management in Asian River Basins, Proceedings of the Workshop held at Hyderabad, India, IAHS Publ. 349, 2011.

10. Popović Lj., Popović Z., Ristić Vakanjac V., Vakanjac B., Mandić M. (2016). Trenutno stanje i moguće posledice nekontrolisane eksploatacije šljunka po životnu sredinu i vodosnabdevanje - primer Velike Morave, XV Srpski simpozijum o hidrogeologiji sa međunarodnim učešćem, Rudarsko-geološki fakultet, Univerzitet u Beogradu, pp. 435-440, Kopaonik, Srbija

11. Vakanjac, B. (2018). Eksploatacija šljunka i uticaj na vodne resurse, Zbornik radova sa nacionalne konferencije sa međunarodnim učešćem: Ekoremedijacija i ekonomska valorizacija vodnih resursa - modeli i primena (editor Rikalović M.) Fakultet za primenjenu ekologiju Futura, Univerzitet Singidunum, pp. 57-62, ISBN: 978-86-86859-57-0 